\title{
Research of the changeability of the vessels traffic intensity of inland waterways - case study for Lower Vistula
}

\author{
Patrycja Jerzyło ${ }^{1}$, Aleksandra Wawrzyńska ${ }^{2}$ \\ ${ }^{1}$ Gdańsk University of Technology, Faculty of Civil and Environmental Engineering, Poland \\ ${ }^{2}$ Gdynia Maritime University, Faculty of Navigation, Poland
}

\begin{abstract}
The article presents an analysis of the changeability of traffic intensity of inland waterway vessels in the Vistula Delta. The concept of traffic intensity was defined, traffic flows and disturbances were identified in the studied area. The characteristics of the inland waterway traffic model are presented. The results of the analysis indicate the need to carry out modernization of inland waterways for the needs of inland waterway transport: introduction of a traffic control system, unification of the navigational marking system and strict correlation of renovation/modernization works of hydrotechnical structures with a navigation period.
\end{abstract}

\section{Introduction}

The common transport policy pursued by the European Union aims at subordinating transport to the principles of sustainable development. This is to ensure real competition between the different modes of transport for environmentally friendly transport and the integration of freight transport corridors using two or more modes of transport. In light of these principles, inland waterway transport, which is environmentally friendly, safe and cheap, occupies an important place in the policy of sustainable development. Inland waterway transportation, providing crucial linkages between domestic and international shipping markets, plays a significant role in promoting the economic development of many countries [10].

Nowadays, the directions and trends of development, as well as the European Union's policy regarding inland navigation are aimed at adapting inland waterways to modern needs of shipping, forwarding and tourism and using inland infrastructure for intermodal transport as an element of handling and forwarding hubs.

The layout and length of inland waterways in Poland has remained at a similar level for years. The specificity of waterway infrastructure influences the factors shaping the demand for inland waterway transport. The navigational conditions translate directly into the basic

\footnotetext{
${ }^{1}$ Corresponding author: patjerzy1@pg.edu.pl
} 
construction parameters of the rolling stock used for inland waterway transport, including the relatively low capacity of barges, as well as the volume of transport [6].

Traffic flow modeling is a mathematical record (structure of demand transport) based on the study of communication behavior in a separate territorial unit, which through the model of transport interactions is designed for traffic forecasting, study of traffic flow changes in the process of planning transport systems, optimization of transport networks, solving transport tasks and supporting decision-making in other transport problems related to transport systems [4].

The vessel traffic stream is described by a number of different parameters, of which the basic and additional parameters are distinguished [1]. The basic parameters are:

- intensity,

- density,

- speed.

In addition, the traffic flow can be described using the following quantities [1]:

- queue spacing,

- time between submissions of subsequent vessels,

- number of vessels traversed by a fixed point of the road at given time intervals,

- directional and generic structure of traffic.

Rivers have long been a communication route along with the development of the river's civilization in the natural state it was necessary to start regulating - to deepen and expand to allow the free movement of ever larger vessels. Poland in terms of nature has very good conditions for using inland transport.

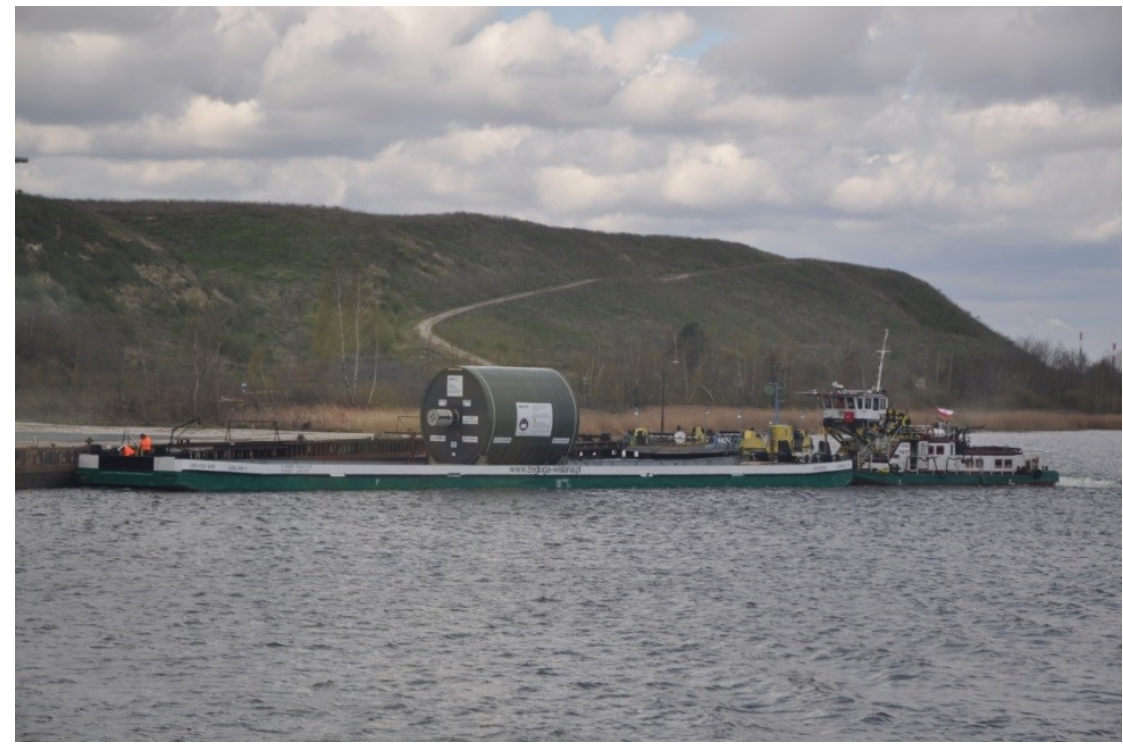

Fig. 1 Transportation of non-normative cargo in 2017 [fot. P. Jerzyło]

Inland shipping, though heavily neglected in Poland, is slowly beginning to develop again (Fig. 1). A dense network of rivers and lakes favors the development of inland transport, however, such good conditions are used to a small extent. The advantage of inland waterway transport is low transport cost, as well as low environmental impact, which in today's world is one of the most important issues. The principle of sustainable 
development assumes such activities to maintain social, economic and environmental balance.

\section{Shipping routes in the Vistula delta}

One of the basic concepts in social sciences (particular in social economic geography), spatial management and economics is accessibility. First of all, it is the occurrence in the socio-economic space of at least two elements being, respectively, the source and destination of accessibility, which are accessible to each other. The second characteristic feature refers to the means of communication, acting as a carrier of connections connecting the previously mentioned points of space, overcoming its resistance in the form of socioeconomic, political and administrative or natural factors. Such perceived availability implies the occurrence of two complementary notions of accessibility - in terms of transport and spatial approach [9].

The use of inland waterways through the Port of Gdansk offers opportunities for the development of the Polish economy by generating lower transport costs compared to land transport due to low transport prices, which result from high degressivity of unit costs, large freight loads over long distances, without significantly interfering in the natural environment [5].

To determine the potential transport accessibility of the Vistula Delta, use: analysis of available infrastructure in the form of ports (Tczew, Malbork, Elbląg, Gdańsk), floating fleet, which can conduct regular navigation in the surveyed area (Figure 2), location of large enterprises whose transport policy indicates for the interest in using transport navigation in logistics processes. The analysis of the condition of the existing waterway is also very important (Fig. 3).

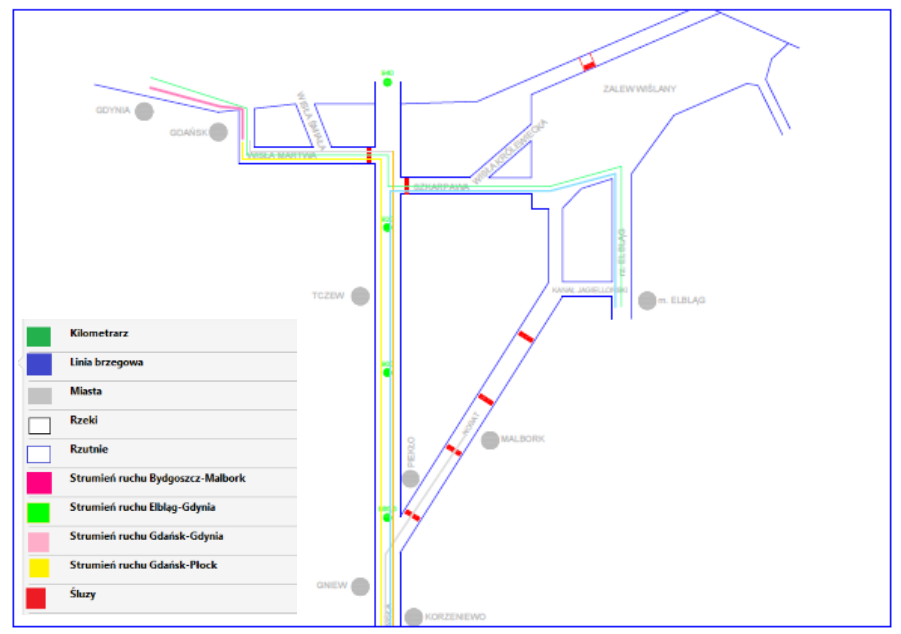

Fig. 2 Ship traffic jets in the Vistula delta between 2010 and 2016 [Own study]

Wisła from $684 \mathrm{~km}$ to Toruń, ie. $718 \mathrm{~km}$, despite being classified to the Ib class of regional importance, does not meet the requirements of this class in terms of transit depth. Transit depths in relation to average water are $1.2 \mathrm{~m}$ in length. During low water depths, 
they fall below $1.0 \mathrm{~m}$, often reaching not more than $0.6 \div 0.7 \mathrm{~m}$. The guarantee required for this class of transit depth is only $5 \%$ the entire navigation period (ie several days a year). Wisła from Torun $\mathrm{km} 718$ to the Port of Tczew at km 910 remains normatively in class II of the waterway of regional significance. It meets the requirements regarding the width of the navigable route $(30 \mathrm{~m})$, the minimum radius of the bowels of the navigable route $(300$ $\mathrm{m})$ and the minimum clearance under the bridges over $(3.0 \mathrm{~m})$. However, it still has a limited transit depth of up to $1.4 \mathrm{~m}$. The guarantee of transit depth required for this class $(1.8 \mathrm{~m})$ is practically up to $10 \%$ of the entire navigational period. The Vistula River from Tczew at $\mathrm{km} 910$ to the mouth of the Gulf of Gdansk remains in the third class of the waterway of regional significance. It meets the requirements regarding the width of the navigable route $(40 \mathrm{~m})$, the minimum radius of the bowels of the navigable route $(500 \mathrm{~m})$ and the minimum clearance under the bridges over $(4.0 \mathrm{~m})$. Does not meet the parameters of the Class III waterway with regard to the transit depth. Depths in the river's depth are limited to $1.6 \mathrm{~m}$, compared to the $1.8 \mathrm{~m}$ required for this class [14].

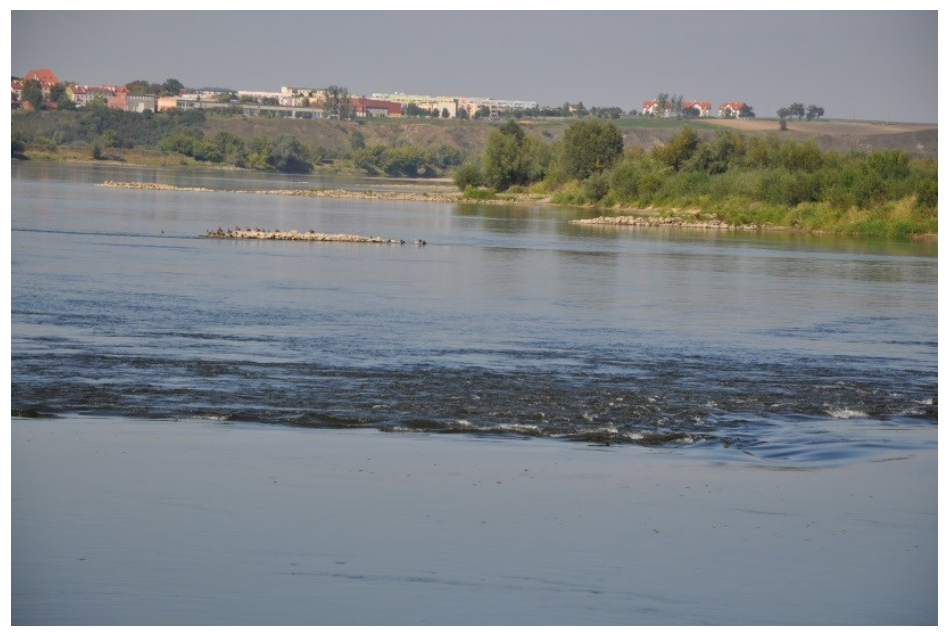

Fig. 3 Regulatory buildings in the Vistula delta [fot. P. Jerzyło]

Nogat from the Vistula River to the estuary to the Vistula Lagoon, the length of $62.0 \mathrm{~km}$ remains in the 2 nd class of the waterway of regional significance. The Nogat River belongs to the II class of a waterway. The section from $\mathrm{km} 0+000$ to $38+650$ is sewered (4 locks: Biała Góra, Szonowo, Rakowiec, Michałowo), Transit depth is $1.80 \mathrm{~m}$. Section from $\mathrm{km} 38$ +650 to $62+000$ - this is the navigable section of the river flowing along with limiting the transit depth to $1.60 \mathrm{~m}$. On the sewered section it meets the requirements regarding the width of the navigable route $(30 \mathrm{~m})$, the minimum radius of the navigable water route $(300$ $\mathrm{m}$ ), mucus parameters (length $65 \mathrm{~m}$, width $9.5 \mathrm{~m}$, depth on the lower threshold of $2.2 \mathrm{~m}$ ) and a transit depth of $1.8 \mathrm{~m}$ [14].

The Szkarpawa River is $25.4 \mathrm{~km}$ long and belongs to the II class of a waterway with a restriction of the transit depth to 1.60 and the radius of the navigable route's curves up to $150 \mathrm{~m}$. It meets the requirements regarding the width of the navigable route $(30 \mathrm{~m})$ and the parameters of the Gdańsk Głowa sluice (length $65 \mathrm{~m}$, width $9.5 \mathrm{~m}$, depth on the lower threshold $2.2 \mathrm{~m}$ ). 
The Martwa Wisła river is $11.5 \mathrm{~km}$ long and belongs to the Vb class of a waterway with a limited width of the lock sluice in Przegalin to $11.90 \mathrm{~m}$. It meets the requirements regarding the width of the navigable route $50 \mathrm{~m}$, the transit depth $2.8 \mathrm{~m}$ and the radius of the navigable route $800 \mathrm{~m} \mathrm{[14].}$

\section{Acquiring data about unit traffic}

Inland waterway is well known as an efficient and reliable transportation mode for economics, with the continuous expansion of trade volume, the traffic density has risen steadily, leading to maritime accident occurred frequently [11].

The information identifying the vessel floating in sea waters and identifying its traffic parameters can be obtained by means of the Vessel Traffic Service (VTS). VTS - these are services provided by competent administration to improve safety, navigation efficiency and environmental protection. This service must be able to interact and respond to traffic related situations taking place in the areas of VTS operations. Another system used to acquire data is the Automatic Identification System (AIS) [7].

In the case of obtaining information on the movements of units on inland waterways, data obtained from the river information system, the aim of which is to improve the safety of navigation, can be used [13].

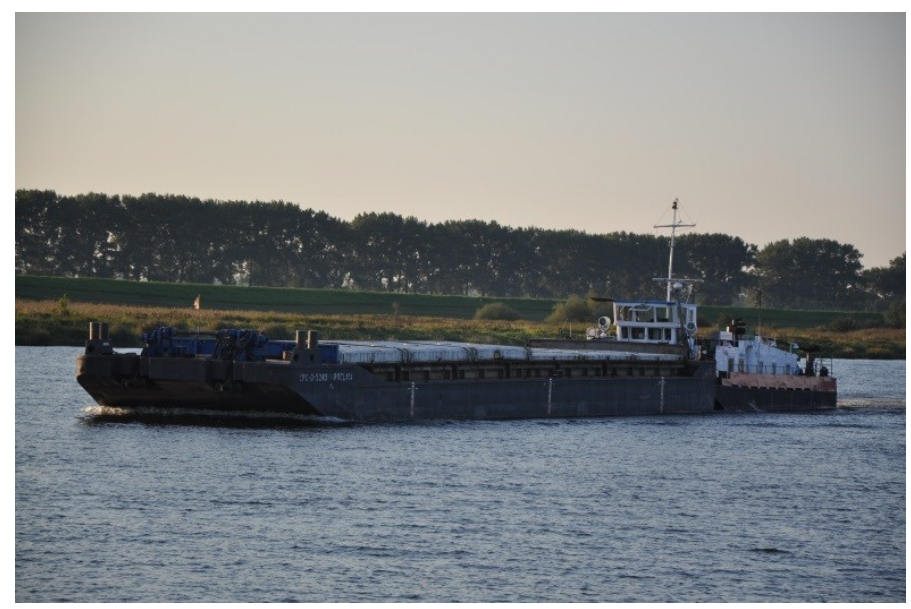

Fig. 4 Transport of mass cargo in 2016 [fot. P. Jerzyło]

Thus the obligation to implement the River Information System (RIS) includes all inland waterways of international importance and the ports located on them, which connect with other roads of the same standard, i.e. from the 4th class of the waterway according to the classification United Nations Economic Commission for Europe (UNECE). The provisions of the RIS Directive, at the discretion of the Member States, may also be applied on inland waterways not covered by this obligation. However, on national inland waterways subject to RIS obligation, but not linked to the waterway network of another Member State, the requirements and technical specifications for a harmonized river information system set out in the RIS Directive are not mandatory but are only recommended. In Poland, most waterways have operational parameters of regional significance. Only less than $6 \%$ of their length meets the requirements of inland waterways of international importance (parameters of class IV and higher), i.e. those subject to the obligation to implement the RIS Directive. They are [13]: 
- Dąbie lake to the border with internal sea waters - $9.5 \mathrm{~km}$

River Odra from the town of Ognica to Przekopu Klucz-Ustowo and further as the Regalica river to the estuary to the Dąbie lake $-44.6 \mathrm{~km}$

- the Western Oder River, which includes:

- from the weir in Widuchowa to the border with internal sea waters together with side branches $-36.6 \mathrm{~km}$,

- Przekop Klucz-Ustowo, which connects the Odra Wschodnia River with the Western Odra River - $2.7 \mathrm{~km}$.

- Parnica River and Przekop Parnicki from the Odra West River to the border with internal sea waters $-6.9 \mathrm{~km}$.

Therefore, the part of the lower section of the Odra river from the town of Ognica to Szczecin is subject to the obligation to implement RIS, along with the Odra Wschodnia, the West Odra, the Dąbie Lake and other roads of the Szczecin water node. The total length of these waterways is $97.3 \mathrm{~km}$. All sections have parameters of international significance and connect with each other. The requirement to develop technical specifications for a European river information system results from the need to build a harmonized, interoperable and open information system, available without discrimination for all system suppliers and users. For safety reasons, it was assumed that the technical requirements and specifications would be based on the work developed in this field by relevant international organizations, such as:

- International Sailing Association (PIANC),

- Central Commission for Navigation on the Rhine (CCNR),

- European Economic Commission of the United Nations (UNECE).

The framework structure of a harmonized river information system should enable system operators and users to achieve their goals by implementing a series of tasks related to inland waterway management, based on the information collected and sent to create the service [13].

The waterway in the Vistula Delta is not covered by any Traffic Control System, River Information System or Automatic Identification System. Data regarding inland waterway transport, unit traffic and transported cargo can be obtained from the Central Statistical Office and Regional Waterways Authority in Gdańsk and an observation method (Fig. 4) for determining the average speed of vessels. This information is obtained with a long time delay and can't be used to model the traffic flow of units in real time. Considering the current use of the navigable route in the Vistula Delta, it seems that this way of acquiring data is sufficient. In the case of an increase in traffic density and density of units moving along this route, it will be necessary to introduce a monitoring system in a continuous movement of units in the studied area.

\section{The intensity of ship traffic}

The model of ship traffic flows is called: the mathematical description the structure of demand transport based on the study of transport behavior in a separate territorial unit. The basis for consideration of models reflecting traffic flows is the measurement and archiving performed correctly.

To describe phenomena occurring on the road, which is the movement of vehicles, modeled in the areas of mathematics, physics and simulation models are used. The models described below are a combination of models:

- macroscopic model - it reflects the flow of motion streams in a certain section or area in which the disruption of a single stream affects the whole system, which causes a change in socio-economic factors. Examples of macroscopic models are: wave motion model, dispersion model. 
- microscopic model - modeling of the movement of a single vehicle, expressed by relations between the unit and the person heading, between units and between the unit and its surroundings. Examples of microscopic models are: driving model with a leader, queue model.

On the basis of data provided by the Regional Economy Board in Gdańsk, the movement of tourist units in 2010 - 2014 in the area of the lower Vistula limited by locks: Przegalina, Gdańsk Głowa, Biała Góra, Czersko Polskie, Miejska in Bydgoszcz and Włocławek (Figure 5) was identified. Tourist units have been qualified for kayaks, sailing boats, rowing boats, motor boats and rafts.

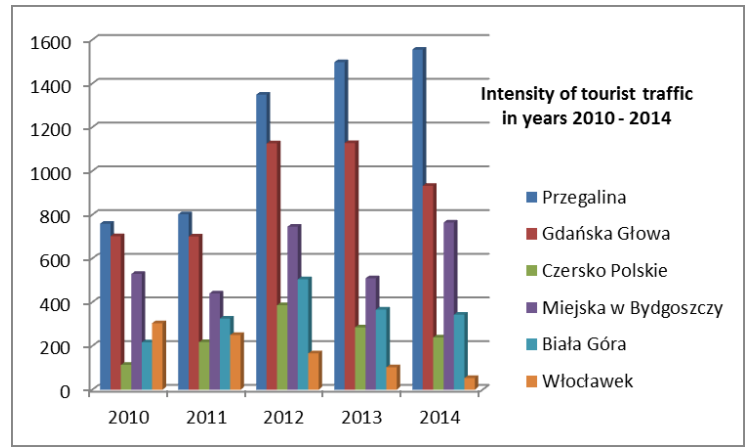

Fig. 5 Intensity of tourist traffic in 2010 - 2014 [Own study]

Analyzing the intensity of movement of cargo units, the following units were taken into account: motor barges, towed barges, pushed barges, tugs, pushers, passenger ships, ferries, icebreakers and wheelchairs (Fig. 6).

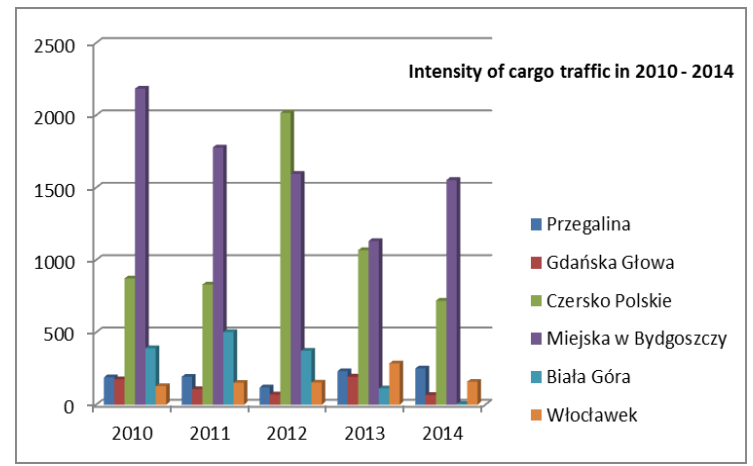

Fig. 6 Intensity of cargo traffic in 2010 - 2014 [Own study]

Intensity is a parameter of the unit traffic flow, specifying the number of vessels traverse the set point on the fairway per unit of time. Intensity is expressed by the formula [3]:

$$
q=\frac{n}{\tau}
$$

where:

$q$ - the intensity of the unit traffic stream,

$n$ - the number of units that traverse a given point,

$\tau$ - the time interval in which the units were registered. 
In the studied area, one of the traverse points is the lock in Przegalina, and the unit of time 2014. Statistical analysis of the number of lockable vessels showed a large variation in the intensity of the ship traffic flow due to the month (Fig. 7). The largest number of units being flown took place in March, which was related to the icebreaking action on the Vistula river and increased number of icebreaker locks.

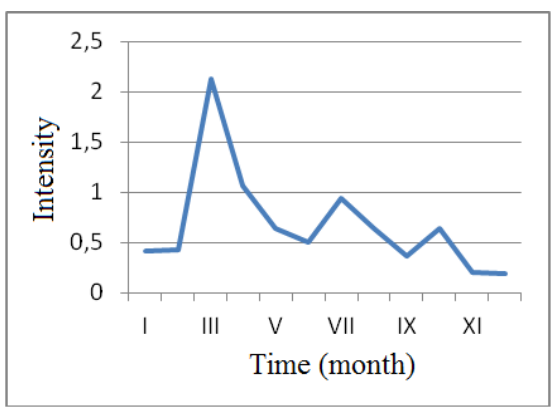

Fig. 7 Intensity of vessles traffic in particular months in 2014 [Own study]

\section{Disturbances in the waterway network in relation to the identified traffic flows}

Traffic modeling in transport networks on waterways is particularly complex. Such an area is a place of strong influence of various socio-economic, technical, organizational and economic factors. This affects the functioning of individual transport subsystems, which on one hand are characterized by distinct features, and on the other - depend on each other. This impact also applies to streams of traffic flowing through the transport network. In this situation even small changes in transport infrastructure may cause disturbances and changes in the traffic structure. The basic problem in modeling the parameters of the units' movement streams are difficulties in navigation, which more or less disturb the random character of the stream.

The basic purpose of modeling in case of disturbance analysis is proper identification of their causes and assessment of their impact level. An appropriate way of mapping the flow of traffic in the waterway network allows taking into account a number of factors that influence the achievement of reliable results. This is particularly important in traffic management, where the transfer of current, reliable and properly formulated information to network users can improve the functioning of the entire transport system [12].

Each user of the transport system realizes his journey within a certain time interval. From the point of view of modeling, the moment of commencing the displacement and the moment when it will be in certain places of the network are important. These can be places characterized by extremely arduous traffic conditions, as well as decision points, when the user has the opportunity to choose a way of moving. However, it is difficult to obtain such detailed information for each transport system user, although they would be very useful for precisely describing the flow of ship traffic flows.

The main components of the unit motion stream model are traffic flow parameters and probability distributions describing these parameters [8]. The basic problem in modeling the parameters of the units' motion streams are difficulties in navigation, which more or less disturb the random nature of the stream. A traffic disruption can be defined as a sequence of 
events leading to a state in which traffic can't be continued according to previous assumptions. In the examined model, the disturbances are, among others: waiting time for sluicing, slacking, low water level (insufficient depth) and temporary shut-off of locks and sections of the waterway. The purpose of such research is to identify places particularly susceptible to interference, to assess the impact of these disturbances on other elements of the transport system on waterways and their surroundings, and to select the appropriate traffic management tools to reduce the nuisances resulting from these disruptions.

Critical nodes of the network are the places of disruption, where the capacity reserves are stuck in liquid streams accompanying disrupted streams. Appropriate change of traffic structure in nodes may lead to improvement of the capacity and reduction of total time losses in the network. Therefore, it is important to accurately identify disturbance locations at the microscopic level [12].

Under real conditions, a single event may not cause a disturbance, and only the appropriate combination of several events will result in disturbances, requiring appropriate actions on the part of traffic management (Fig. 7).

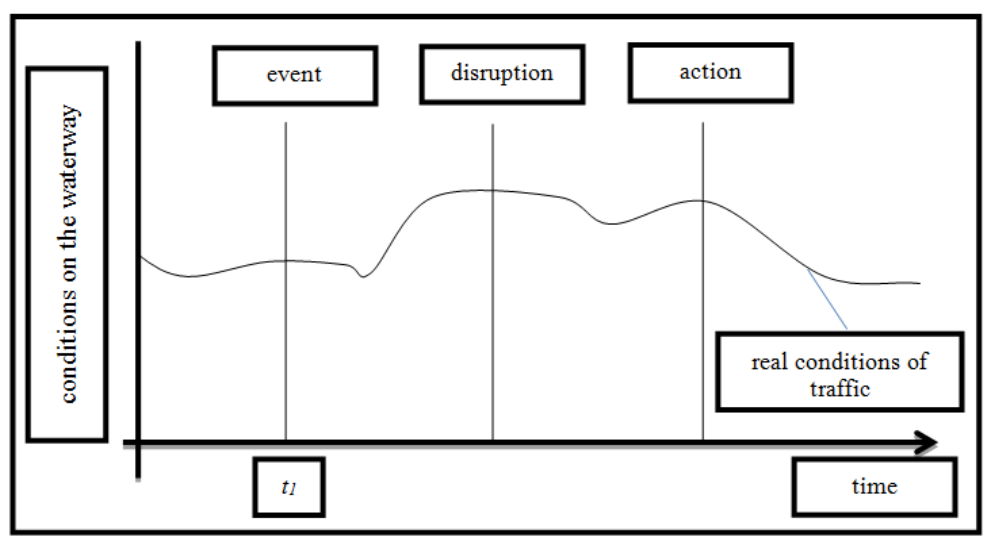

Fig. 7 Influence of disturbance on conditions occurring on the waterway [Own study]

Any disturbance may cause a violation of the prevailing conditions, and thus a decrease in the quality of the displacement. Therefore, an appropriate level of disturbance should be assumed, corresponding to a defined level of traffic loss, beyond which the effects of disturbances are felt by the network users. This level is strictly conditioned by the specificity of the area. Acceptance of specific traffic conditions and the related quality of movement is subjective and depends on both the user's characteristics, the period of the day, the type of travel, as well as the function and location of the elements of the transport network.

For the purpose of assessing traffic conditions in the network, a set of interference types has been defined:

$$
R_{z}=\sum_{i=1}^{z} z(s, t, v,)
$$

where:

$R_{z}$ - the size of the set, i.e. the number of disturbances accepted for analysis,

$i$ - reference stream,

$z$ - measure of the assessment - disturbances,

$s-$ road,

$t$ - time,

$v$-vessels in the disturbed traffic stream. 
Interesting area characteristics calculated in this way include distribution of the number of disturbances in the network in relation to traffic flows. Measures of interference in the network are defined by the user for each network in the form of an acceptable drop in the speed of units, at which the movement of units is not considered to be disturbed yet. The distribution of the number of disturbances is determined for all (or selected) traffic flows globally in the area of the entire network as well as locally for each user-defined spatial unit in this network. It can be expected that there is a proper organization of traffic for a given network and is characterized by some statistical ordering (defined by the function of the density of the distribution or the composition of such functions as intensity, disturbances, length of queues, etc.).

The correct organization of traffic should lead to optimal use of all available infrastructure and organizational resources in a given network.

\section{Summary}

Inland shipping has been neglected for some time in Poland and is slowly beginning to develop again. A dense network of rivers and lakes is conducive to the development of inland transport, however, such good conditions are not yet fully used. The principle of sustainable development assumes such activities to maintain social, economic and environmental balance so that the next generations can benefit from what is now. It is worth considering the initiative of investing in inland transport in order to bring benefits not only to us, but also to future generations.

Traffic models are used in controlling ship traffic to predict the impact of control decisions on traffic efficiency. Adaptive cruise control systems must ensure that the measurement data can be processed in real time. Therefore, a compromise is needed between the accuracy of the vessel traffic model used and its computational complexity.

Current methods of ship traffic control are based mainly on macro and mesoscopic models. Such models include parameters defined for streams or groups of ships. They do not describe the movement of individual ships, and hence, do not allow full use of the information that can be obtained thanks to new traffic monitoring technologies (including sensor networks and video-detection).

Data concerning individual ships (eg location, speed, class, relation) are important and useful from the point of view of traffic control tasks.

The waterway in the Vistula Delta is not covered by any Traffic Control System, River Information System or Automatic Identification System. Data regarding inland waterway fleet, unit traffic and transported cargo can be obtained from the Central Statistical Office and the Regional Waterways Management in Gdańsk and an observational method for determining the average speed of vessels. This information is obtained with a long time delay and can't be used to model the traffic flow of units in real time. Considering the current use of the navigable route in the Vistula Delta, it seems that this way of acquiring data is sufficient. In the case of an increase in traffic density and density of units moving along this route, it will be necessary to introduce a monitoring system in a continuous of vessels traffic in the studied area.

\section{References}

1. Gaca S., Suchorzewski W., Tracz M., Inżynieria ruchu drogowego. Teoria i Praktyka, (Warszawa 2008)

2. Gucma S., Gucma L., Zalewski P., Symulacyjne metody badań w inżynierii ruchu morskiego, Wydawnictwo Naukowe Akademii Morskiej w Szczecinie, (Szczecin 2008) 
3. Kasyk L., Probabilistyczne metody modelowania parametrów strumienia ruchu statków na akwenach ograniczonych, (Radom 2012)

4. Krych A., Słownictwo kompleksowych badań $i$ modelowania potoków ruchu, II ogólnopolska konferencja Naukowo-Techniczna: Modelowanie podróży $i$ prognozowanie ruchu, (Kraków 2010)

5. Główny Urząd Statystyczny, Urząd Statystyczny w Szczecinie, Żegluga śródlądowa w Polsce w latach 2010-2013, (Warszawa 2014)

6. Główny Urząd Statystyczny, Transport wodny Śódlądowy w Polsce w 2014 r., Opracowanie sygnalne, (Warszawa 2015)

7. Pawlak M., Piaseczny L., Modelowanie ruchu jednostek morskich dla określenia emisji związów toksycznych spalin, Czasopismo Techniczne z.7-M/2008, (Kraków 2008)

8. Puszcz A. Gucma L., Wplyw liczebności pomiarów na estymacje parametrów strumienia ruchu statków, Proceedings of the XIV International Scientific and Technical Conference on Marine Traffic Engineering, (Szczecin 2011)

9. Wiśniewski Sz., Dostępność transportowa Uniejowa - ujęcie regionalne, Biuletyn Uniejowski, Tom 3, (Uniejów 2014)

10. Xie, Zhaoqing; Liu, Qing., LSTM networks for vessel traffic flow prediction in inland waterway, IEEE International Conference on Big Data and Smart Computing (BigComp), (Shanghai 2018)

11. Yan, X. P.; Wan, C. P.; Zhang, D.; et al. Safety management of waterway congestions under dynamic risk conditions - A case study of the Yangtze River, PPLIED SOFT COMPUTING Volume: 59 Pages: 115-128 (Published: OCT 2017)

12. Żochowska R., Modelowanie potoków ruchu w sieci miejskiej dla potrzeb analizy zakłóceń, Logistyka 4/2014, (Warszawa 2014)

13. [Online] Available: https:// www.ris-odra.pl/. [Accessed: 22-Feb-2018]

14. [Online] Available: http://rzgw.gda.pl/. [Accessed: 01-March-2018] 